\title{
A SYMBIOTIC RELATION OF COOPERATIVE SOCIAL HOUSING AND DISPERSED TOURISM IN HAVANA VIEJA: DEVELOPMENT MODEL AND ARCHITECTURAL PROTOTYPES
}

\author{
Iwo Borkowicz* \\ Kris Scheerlinck** \\ Yves Schoonjans $* * *$
}

\begin{abstract}
It is common knowledge that Cuba's inhabitants struggle with huge daily-life challenges. One of the biggest problems is the housing-shortage, with up to $30 \%$ of the society awaiting housing provision (Rodriguez, 2014). They are not literally homeless, as Cuba has adhered to a communits system of governance and grants housing by accommodating people mostly into existing, often extremely overcrowded houses with even four generation of families living in tworoom apartments (Rodrigvez, 2014). Havana, and especially its Old Town (Havana Vieja), struggles with extremely high levels of deterioration of its urban fabric and houses. In 1990, two collapses of buildings were recorded by UNESCO every three days (PDHL, 2000). The housing market is in clear crisis on both an economic and a social level. On the other hand, a very dynamically growing part of Cuba's economy is tourism (Peters, 2014). To decrease the pressure of hotel demand on the national governed sector and implementing a subtle change in dealing with entrepreneurship to regenerate the city, Cubans are now allowed to rent rooms to tourists. Since 2010, the government introduced an updated bill, allowing individuals to move from a national-employment to self-employed sector choosing from a list of one hundred and eighty one permitted professions. This paper explores the development of an alternative growth model for urban and social resilience to regenerate the city-center of Havana. It is based on a researchstay, interacting with local actors next to data-mining. This paper is the result of a search for development-patterns combining solutions addressing the housing shortage through integration of small scale tourism entrepreneurship within it and proposing architectural prototypes to implement the model. The proposal seeks to deal with the urban, economic and social aspects of the productive and regenerative city, empowering the local community, to obtain the necessary
\end{abstract}

\footnotetext{
* Iwo Borkowicz, Department of Architecture, KU Leuven, Belgium. Email correspondence: iwo.borkowicz@gmail.com

** Kris Scheerlinck, Department of Architecture, KU Leuven, Belgium. Email correspondence: kris.scheerlinck@kuleuven.be

*** Yves Schoonjans, Department of Architecture, KU Leuven, Belgium. Email correspondence: yves.schoonjans@kuleuven.be
}

tools to face the challenging future of Havana and its inhabitants.

Keywords: Havana Vieja, dispersed tourism, housing shortage, research-by-design, development model, new models of productivity.

\section{INTRODUCTION}

Cuba is a country of eleven million inhabitants. The Cuban government officially acknowledges that in order to grant its people access to humane housing conditions it needs to build five hundred thousand new housing units $(20 \%$ of which in Havana). Outside sources suggest that this number can be as high as a million (Rodriguez, 2014), theoretically making one third of Cubans homeless. Currently excessive number of inhabitants live in existing flats and houses, under very poor living conditions. Due to difficult economic condition of the country, people no longer get financial help from either the Soviet Union nor Venezuela, which is also taking its toll on the countries ambitions of dealing with the housing shortage.

Cuba, being a Communist country, faces the issue of managing private property, as private property is very limited. Land and housing policies are such that majority of the locals get access to housing through a system where private property ownership is discouraged. The Cuban government has recently experienced with legalizing market mechanisms for ownership of private housing.

Historically Cuban households have legally owned their homes but with some limitations. In November 2011, the Cuban government legalized free market sales and other measures aimed at bringing to the surface an underground market that was largely unregulated. Some of the measures 
undertaken by the government included expansion of self employment and the start of urban worker cooperatives.

The new system requires the buyer and seller of property to complete necessary paper work before a specialized lawyer, payments are to be made through banks, income and property transfer taxes are to be paid and residents are only allowed to own one residence and a second property in a vacation area.

According to National Housing Institute figures released in September 2013, Cuba needs to build 60,000-70,000 new housing units per year to alleviate its housing deficit. But only a fraction of that number is being built, which is 16,000 units per year by the state at the current rate, and 8,00010,000 by homeowners themselves. Natural disasters destroy homes every year, for instance Hurricane Sandy alone destroyed 22,396 homes in eastern Cuba in 2012 (Peters, 2014).

Although, since 2011 Cubans can sell and buy houses in the open market but Cuban banks don't give out loans bigger than $\$ 40$ or so, when a modest housing unit costs thousands of dollars (Grein, 2015). Additionally Cuban cities, especially Havana, are facing great deterioration of its urban fabric, leading to common building collapses.

A combination of age, decay, neglect and other elements threaten important nineteenth century neoclassical villas and Spanish colonial mansions, along with some of the world's finest examples of twentieth century architecture, Art Deco palaces from the 1930s and modernist structures from the 1950s' (Sanchez, 2009).

Cuba introduced programs like the Office of the Historian of the City of Havana (OHC) that deals with this problem. Additionally in 2010 a small part of the economy was opened for private business initiatives in order to repair the national budget. Since then over half a million Cubans moved into self-employment related to the tourism industry.

Since 1997 tourism is the biggest, and most dynamically growing drive of Cuban economy (Figueras, 2003). In 2015 over three million people visited the island. Touristic infrastructure is not prepared for that many tourists and the hotel shortage is visible. Due to a renewed diplomatic relations between Cuba and United States, American tourists will be travelling to the island with ease, which will surely lead to a even more dynamic growth of visitors. The government is not willing to simply allow international companies to enter the island and deal with the growing demand of tourism as it is afraid of them feeding on this financial potential, leaving Cubans aside.

Mass tourism is also threatening Cuban cities, especially the district of Old Havana which is the main touristic attraction of the country. Negative impacts of gentrification may lead the oldest Cuban housing district into becoming a theme park, pushing original inhabitants out to the outskirts and destroying the authenticity of this district.

This paper explores the alternative growth model for urban and social resilience to regenerate the city-center of Havana and looks into the relationship between housing and touristic shortage in Cuba.

\section{NEW STRATEGIES FOR OLD HAVANA}

Housing shortage in Cuba is caused mostly due to the fact that Cuba does not have money to build or renovate houses. The present hotel industry in Cuba does not suffer from financial issues, but is not allowed to grow freely, especially in Havana Vieja, as it is expected that the impact of mass tourism can be dangerous, if not checked by the government.

What if one were to merge those two into a typology that could create both housing and hotel capacity? A mixed typology could prevent from big companies ruling the market of Cuban tourism, which could fuel polarization. At the same time this way of addressing the issue would not stimulate gentrification of the district, which Havana Vieja is at a huge risk of. Lastly, this idea, through its flexibility, could address the changing dynamics of the touristic demand in a sustainable way.

Buildings in areas that attract tourists would consist of regular flats for Cubans and a proportionate number of hotel units weaved into the landuse plan. This would become a source of income for the locals to pay off the loan taken for the construction of the building itself. Cuban inhabitants would be able to make a living through the hospitality business.

This kind of typology could lead to a network of guest houses dispersed among the housing fabric of the whole district, avoiding unnecessary attention hubs around hotel premises. The touristic income would spread more evenly among its inhabitants and the streetscape could maintain its scale and character. Competition between the touristic Old Havana and the non-touristic localities would be minimized, as the whole district would become mixed use leading to sustainable outcome. 
Additionally the political reality in Cuba is characterized by a great level of governmental control of the market so the government can adopt this measure and resist the temptation of fast and lucrative solution of inviting international hotel chains into the country.

\section{HAVANA VIEJA}

The restoration of Old Havana, a 0.826 square mile district containing some 3,370 buildings and 66,750 residents, which was declared a UNESCO World Heritage site in 1982, has been carried out under a unique model of self-financing and sustainability, that has achieved worldwide recognition. Since 1993, the Office of the Historian of the City of Havana has had broad authority over all planning, land use, development, and investment activities within the historic district, including the ability to develop and operate stores and hotels, tax businesses, carry out construction projects, and use its earnings to finance housing renovations, community facilities, and social services for local residents (Achtenberg, 2013).

Despite the rightful actions of the OHC, Havana Vieja is still struggling with housing and hotel shortage, as well as deterioration of old structures. About fifty percent of the Old Town's buildings are classified as being in a bad condition (Coyula, 1997).

Satisfying the hotel demand at peak point of the touristic boom, with the typical hotel typology will lead to many empty buildings in the months after the peak season. Furthermore, the pace in which $\mathrm{OHC}$ is dealing with the housing shortage is not satisfactory. The idea of merging both housing and hotel units in one typology is capable of creating new housing quicker. In the face of coming changes on the island, the fact that Cubans are living in humane conditions and have less access to steady salaries is very important in order to empower the society in the challenging times of the transformation.

"Tourism may bring about irreversible losses and distortion to the city, but it is also one of the few affordable means to garner the capital necessary for urban conservation" (Coyula, 1997).

In 1997 the Cuban government allowed Cubans to rent out rooms in their houses or apartments to tourists, providing Cuban families with new sources of income (Hunt, 2016). As previously, any other type of accommodation in Cuba such as hotels and motels have been owned by the government, the term "casa particular" can be used to highlight that this kind of paid lodging is privately operated. It will create a network of smaller guesthouses, that will evenly spread among the urban fabric, giving access to this kind of income to many families. At the same time, the relation between the tourist and a Cuban will become much more valuable than the one in a typical hotel. Cubans can become hosts and visitors will have a chance of feeling little less as a tourist and more like a part of a real city.

\section{FINDINGS}

\section{Spatial Dimension of the Context}

Havana Vieja is one of the densest district on the island, with 24,000 inhabitants per square kilometer. The question then arises, if there is enough space to built both the necessary missing housing and fit additional hotel units in the district? (Figure 1).

Havana Vieja is home for 97,000 people what makes of $4.6 \%$ of Havanas total population. Havana as a whole needs to generate from 100,000 to 200,000 housing units in order to eradicate the housing shortage. With the highest shortage estimation, Havana Vieja proportionally would need to generate 9,200 new housing units.

For this calculation an area representative of twelve city blocks was selected.

By cross-checking the maps of building heights and vacant plots, a simplified volumetric model of that area was created on which the following calculations were conducted (Figures 2 and 3 ).

Each building's footprint was multiplied by the amount of floors it has, than the total floor area was calculated.

1 or 2 floors $-33.763 \mathrm{~m}^{2} \times 1,5=50.644 \mathrm{~m}^{2}$

3 floors $-6.685 \mathrm{~m}^{2}$ x $3=20.055 \mathrm{~m}^{2}$

4 or more floors $-9.061 \mathrm{~m}^{2}$ x $5=45.305 \mathrm{~m}^{2}$

vacant plots $-1.945 \mathrm{~m}^{2}$ x $0=0 \mathrm{~m}^{2}$

Ruins- $1.500 \mathrm{~m}^{2}$ x $0=0 \mathrm{~m}^{2}$

Outcome: the area of $52.954 \mathrm{~m}^{2}$ generated $116.004 \mathrm{~m}^{2}$ of floor area. 


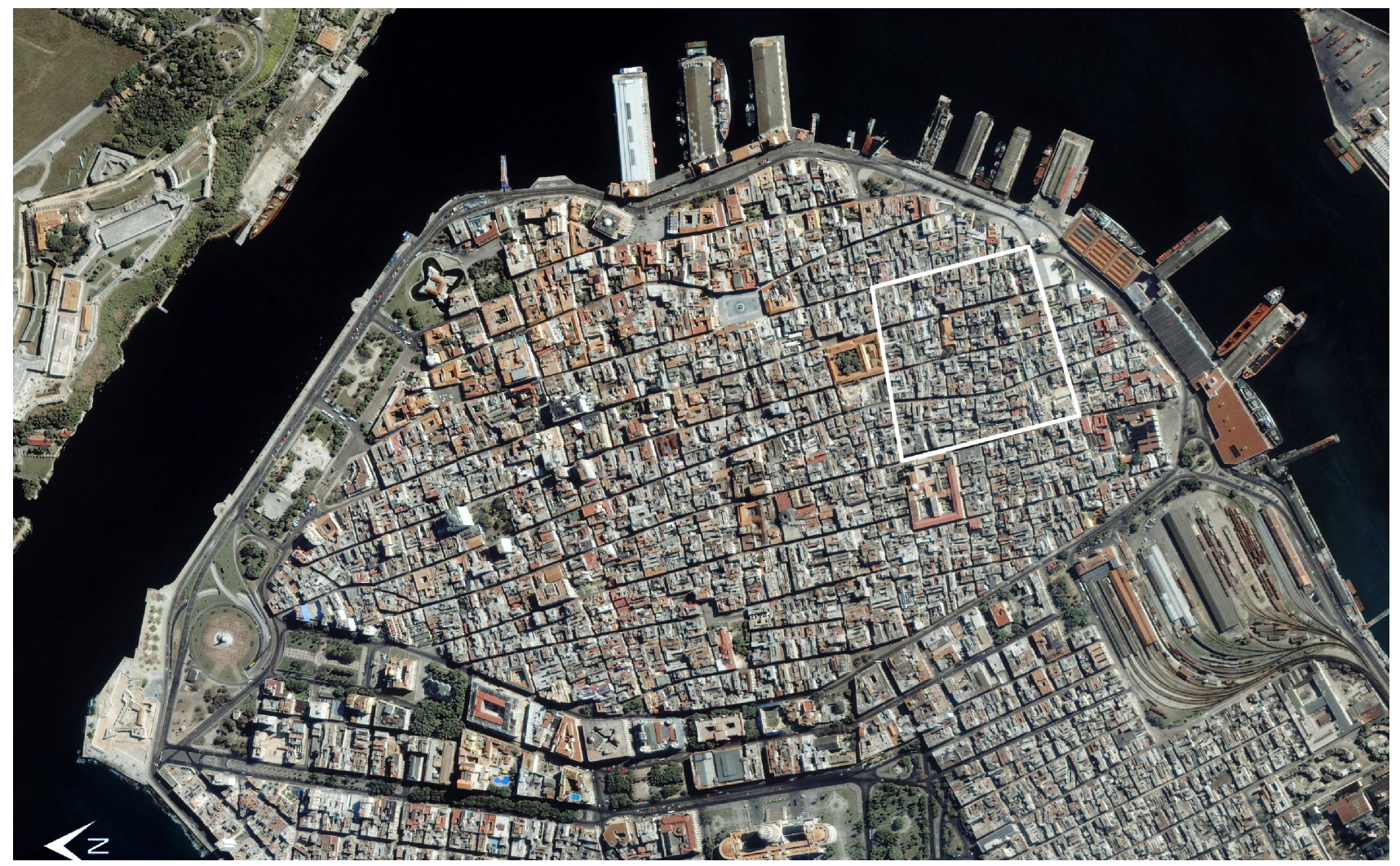

Figure 1: Havana Vieja and the case study area (white outline).

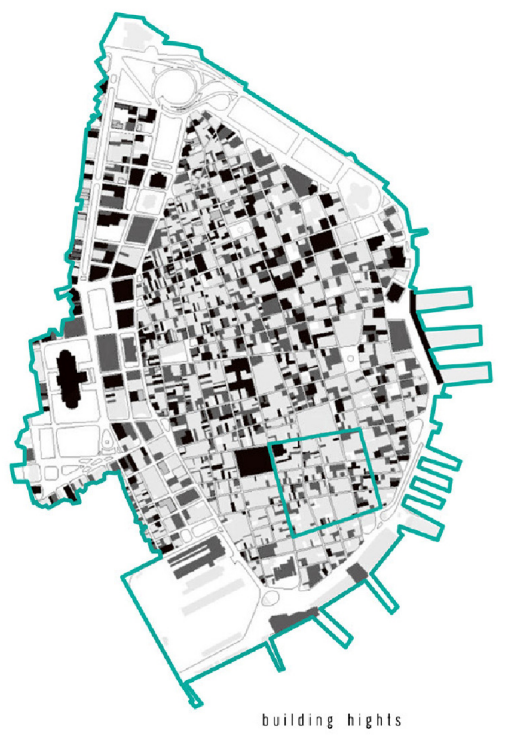

Dover 4 stories

3 stories

$1-2$ stories

$\square$ no buildings

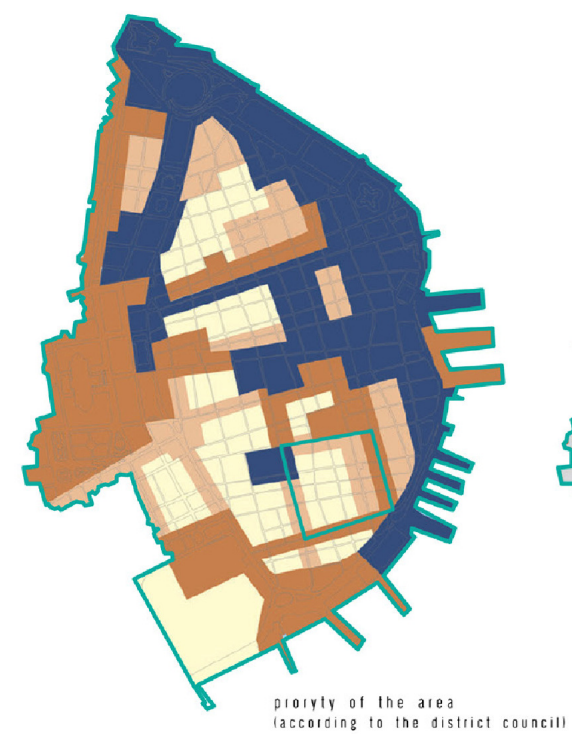

D top

high

medium

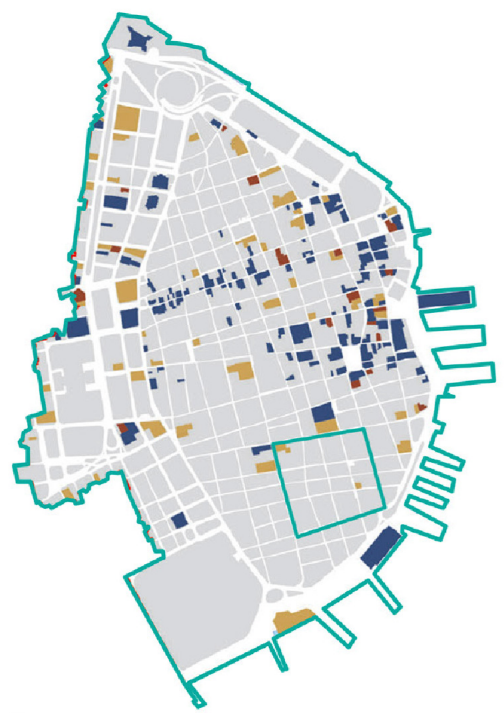

- existing commercial premise

potential hote

existing hotels

Figure 2: Havana Vieja and Case study area placement 


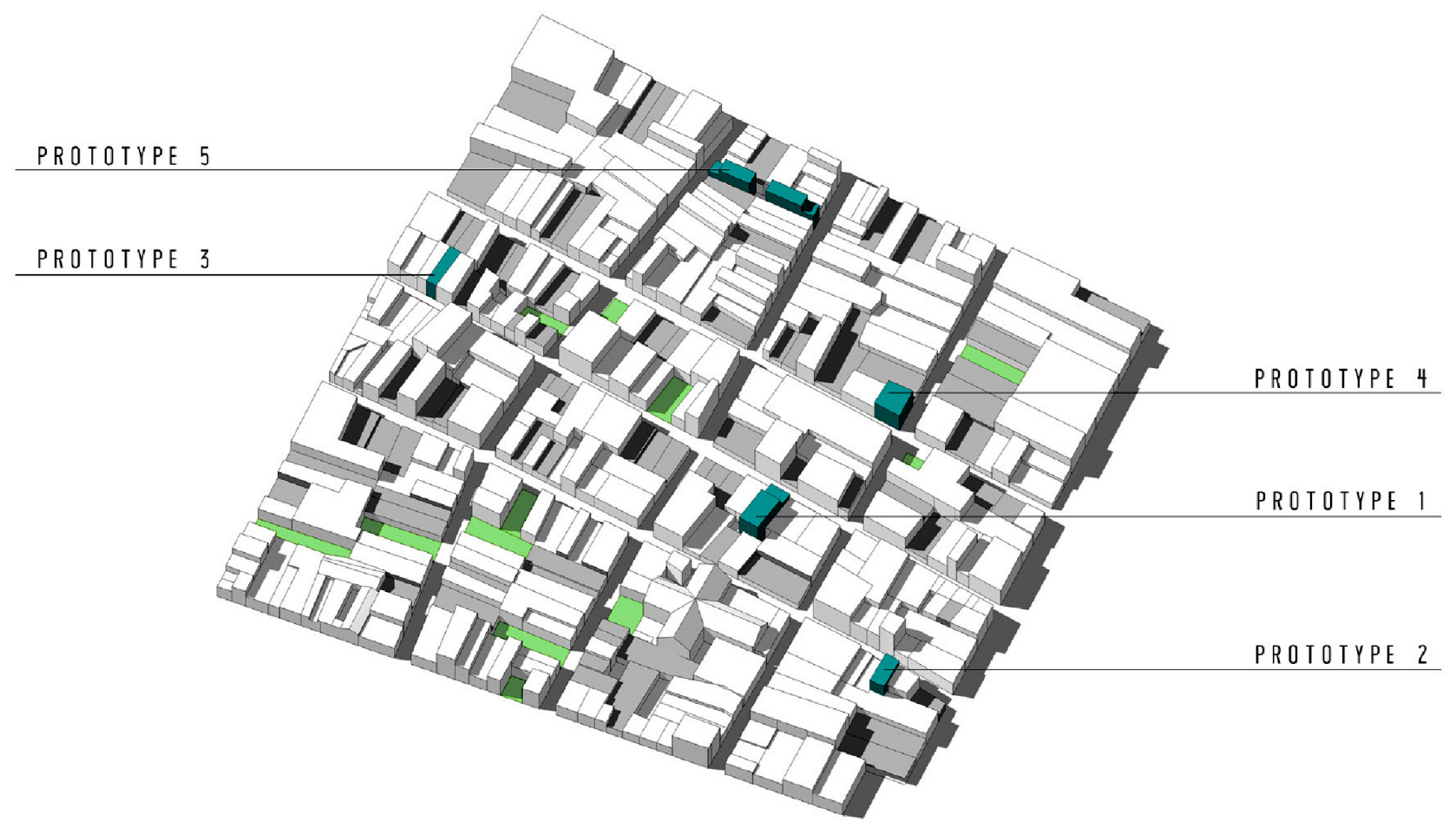

Figure 3: Prototypes

\section{Possible Efficiency}

Following the previous calculation, the existing situation was confronted with the hypothetical model, where on average all the buildings were assumed to be four storeys high.

Now: $116.004 \mathrm{~m}^{2}=100 \%$

If 4 floors high: $221.816 \mathrm{~m}^{2}=182 \%$

Next step was to calculate how many new housing units would need to be created within the boundaries of these twelve city blocks, in order to succeed in building 9,200 new housing units in Havana Vieja.

Housing area of Havana Vieja $=1,266,100 \mathrm{~m}^{2}=97,000$ inhabitants

Housing area of the twelve blocks $=60,396 \mathrm{~m}^{2}=4.7 \%$ of Havana Viejas housing area.

9,200 new housing units $x 4.7 \%=432$ new housing units would need to be created in the boundaries of the analyzed area.
An average of $70 \mathrm{~m}^{2}$ for a housing unit was assumed.

432 units $* 70 \mathrm{~m}^{2}=30,240 \mathrm{~m}^{2}$ of additional floor area needed.

If these 12 blocks would achieve the average height of 4 floors, than additional $105,812 \mathrm{~m}^{2}\left(221,816 \mathrm{~m}^{2}-116,004 \mathrm{~m}^{2}\right)$ of housing area would be generated.

\section{Result}

The estimations were made on the assumption that $20 \%$ of all plot would consist of patios, in order to provide proper ventilation, and $20 \%$ of the building floor area will be circulation. The number decreased to $60 \%$ of $105.812 \mathrm{~m}^{2}$, giving $64.545 \mathrm{~m}^{2}$ of new floor area for housing. As the calculated area needed was $30.240 \mathrm{~m}^{2}$, it was clear that Havan Vieja could generate the additional 9200 new housing units within its boundaries, by achieving the average height of building of four floors, still leaving additional space for hotel units also (Figures 4 and 5). 

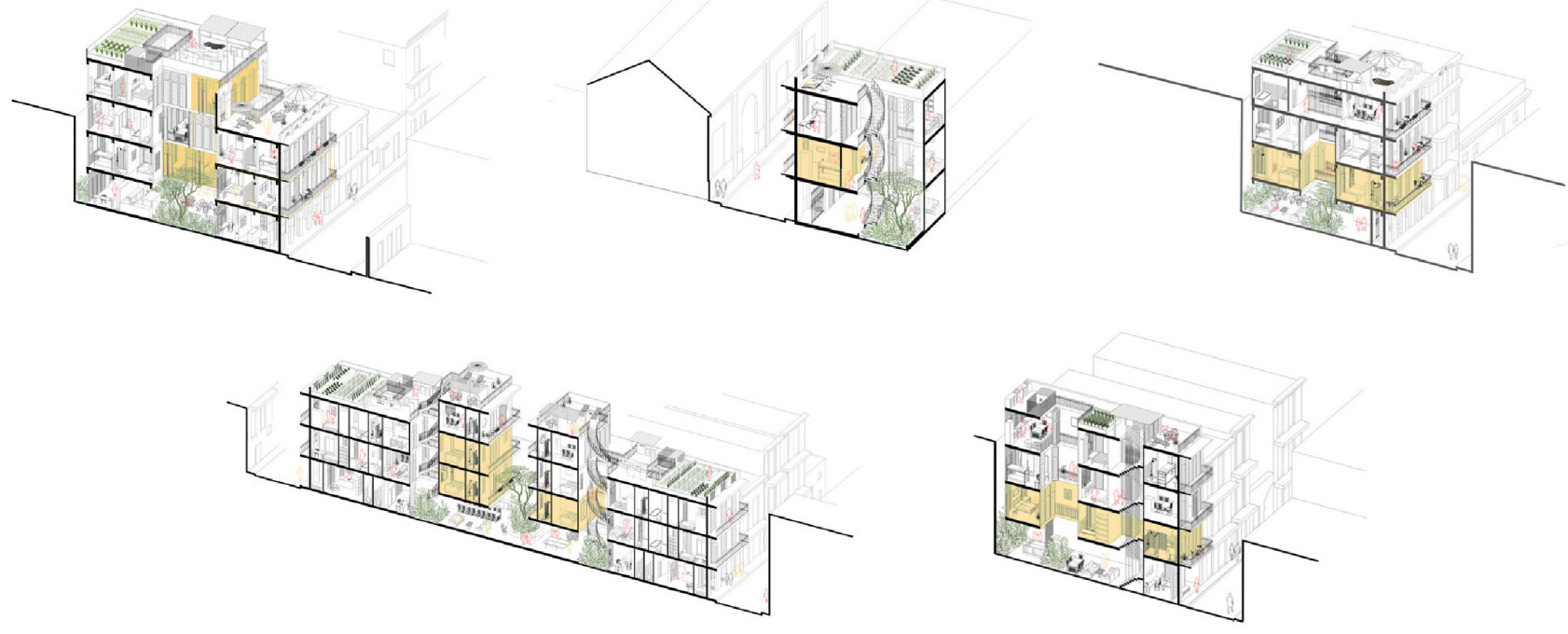

Figure 4: Sections of prototypes.

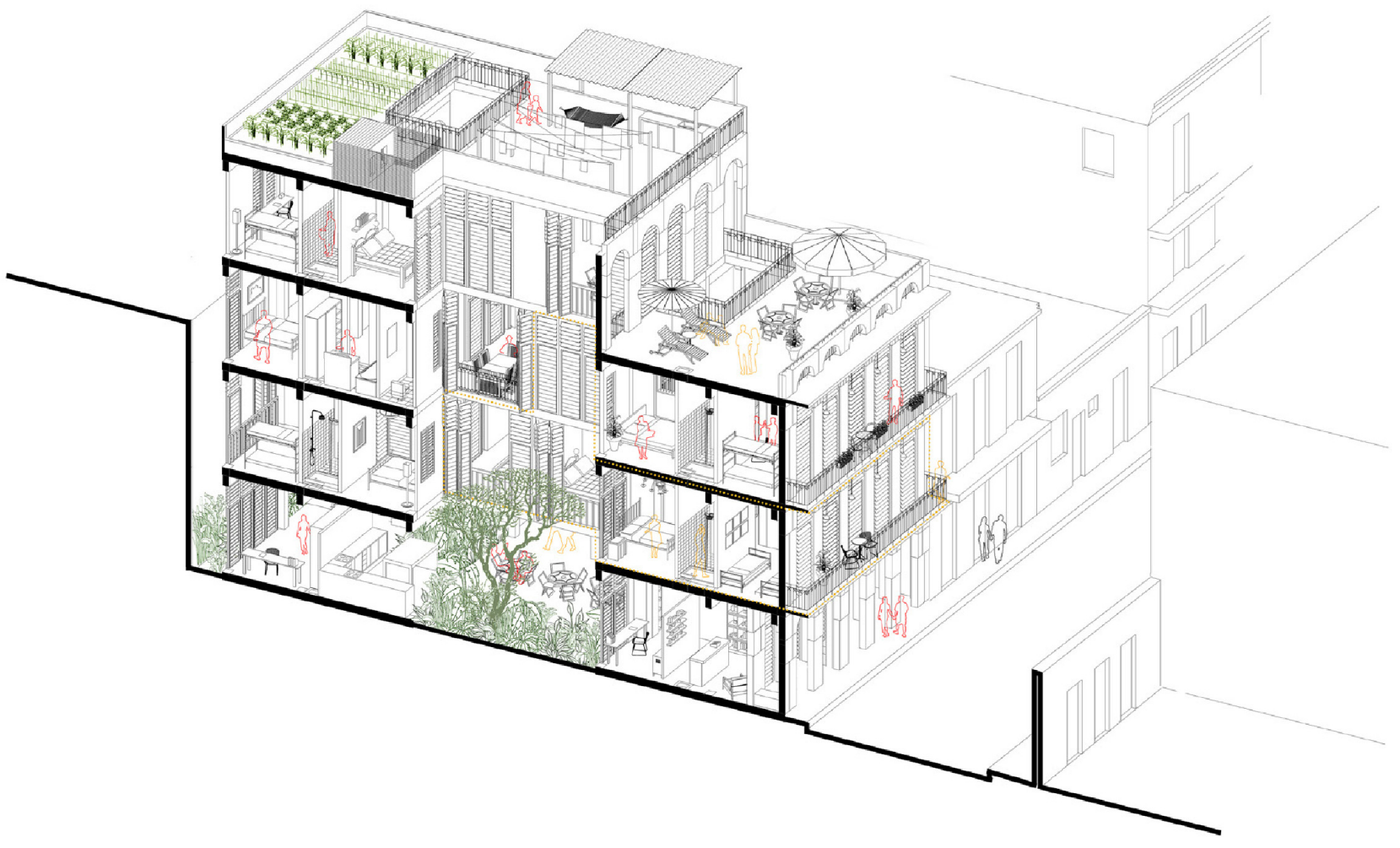

Figure 5: Section of prototype 1. 


\section{Financing Calculations and Demand}

As the capital city is the main touristic attraction on the island, $90 \%$ of tourists visiting Cuba spend on average two nights in Havana. For this calculation it is assumed that in 2017 Cuba will be visited by 3,500,000 tourists. One needs to remember that this number most certainly will dynamically grow much higher in coming years (Associated Press in Havana, 2015).

This statistically meant that on average 17,260 tourists would be in Havana every night for a full year. To continue the estimation, an assumption was made that $33 \%$ of tourists visiting the capital city would like to be accommodated in Havana Vieja district. This gave a demand of 5,753 beds in Havana Vieja alone (nowadays 600 bed'n'breckfast rooms exist in Havana Vieja) (Feinberg, 2013).

\section{Income, Costs and Program Proportions}

Prices on AirBnB (website for holiday rentals) for a room in Havana Vieja varies from US\$30 - 110 per night. For the following calculations an average price of US\$50 per person per night was taken.

A double room occupied for $50 \%$ of the year, 183 days, would generate US $\$ 18,300.10 \%$ of that would consist of wages for Cuban hosts. That would supply two people per family with wages four times higher than the current average salary. Next $10 \%$ would be granted for the operational costs. This will lead to a room creating as much as US\$14.640 of income annually.

The building proportion calculated was set with every apartment for Cubans being balanced with at least one hotel unit. $70 \mathrm{~m}^{2}$ of housing was accompanied with $20 \mathrm{~m}^{2}$ of hotel unit and $10 \mathrm{~m}^{2}$ of circulation.

The cost of construction of $1 \mathrm{~m}^{2}$ of social housing in Chile is US\$ 500. Cuba has a cheap work force, but building in a context of the Old Town requires a little more than the lowest possible budget. For the following calculation an average budget of US $\$ 1000$ per $\mathrm{m}^{2}$ is assumed.

Thus, $100 \mathrm{~m}^{2}$ of construction would cost US\$100,000, with an income of US\$14,640 yearly it would pay itself off in 6.8 years. By adding unexpected costs and loan interests, it is safe to assume that this kind of typology in Havana Vieja has a good chance of being able to pay itself off in under ten years.

\section{Dispersed Tourism}

One of the question that arises is how would Havana Vieja look without chained-brand nor other big sized hotels? If one was to fulfill this demand only with the use of guest rooms woven into the housing fabric, an average of 1.5 tenant buildings with four hotel units each would be required for every city block of the district.

This unusual approach was with success adopted by a Chilean City of Valpariso and one can see a lot of advantages of those decentralized tactics. Often big sized hotels are destructive for an old town fabric, where dispersed hotel units could be gently integrated within it. The income is spread more evenly among the society and more workplaces are created. Tourism industry, if integrated appropriately and hidden, can decrease any destructive capabilities. Finally this kind of market is more flexible and can react do the dynamics of the fluctuating demands and be more sustainable.

Cuba has a strong history in cooperative housing, as cooperation is a core value of the Revolutionary Cuba. For decades, Cubans have gathered and created different types of cooperatives.

The proposed project is trying to learn from these lessons and build upon this tradition. A structure of Housing Cooperative is proposed, where all inhabitants of a built tenement will be part of a group, collectively responsible for taking care for the hotel units and its guests. They would also be collectively responsible for generating the revenue that will pay off the loan taken to built the tenement itself.

The project proposes a solution that will prevent the outflow of original inhabitants from their long inhabited neighborhoods, thus prevent gentrification. In order to achieve this a choice of inhabitants would be structured as an open-call. After the district defines the localization suitable for this type of social housing construction, families would apply for an apartment. Social workers would analyze the applications and create a cooperative group of families (where proximity to their original apartment and the necessity of them being moved, would be prioritized).

The other possibility is a group of families to come together, create a housing cooperative and apply for a participation in the program, after which the municipality will look for a plot and assign a loan for construction, that can later be paid off by the income from the hotel units. 


\section{Space Negotiation}

Due to a magnitude of the Cuban housing crisis, the proposed apartments cannot offer residents high spatial comfort. Apartments would be planned to be useful and efficient, and despite their limited size would offer comfort and privacy. The project proposes to add territorial layers to the housing typology, by offering a set of bigger multi-use collective spaces that both tenants and guests would be a part of. Most of the ground floor of each building would be an open space with planted areas, with sun light entering inner courtyards. In between them an open kitchen and living room would be planned. Guests could be offered meals there or on the roof terrace. Tenants could use this space on a daily basis, as well as for special occasions like common tenement meals, fiestas or for example sports event celebrations, which Cubans love to follow. At the same time, if that space would be used like an extension of each apartment, a sense of community would be enhanced and social control of the entrance zone would be created.
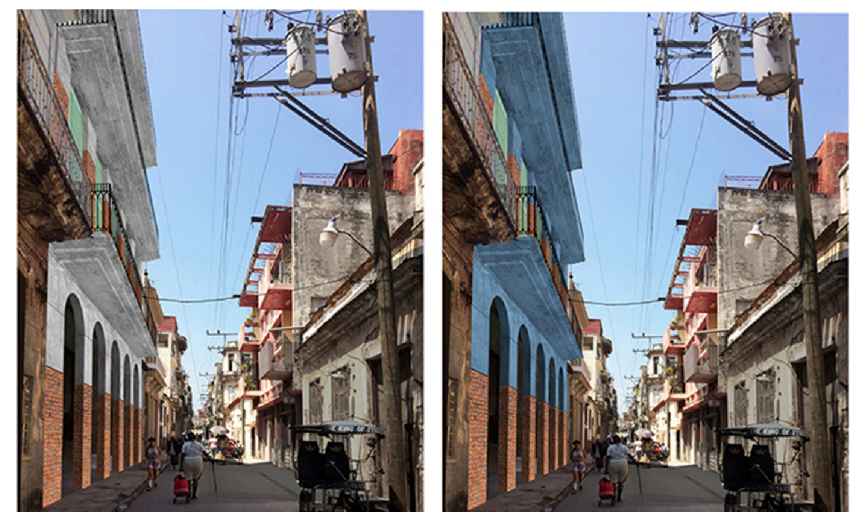

Figure 6: Possible facade expressions of prototype 1.
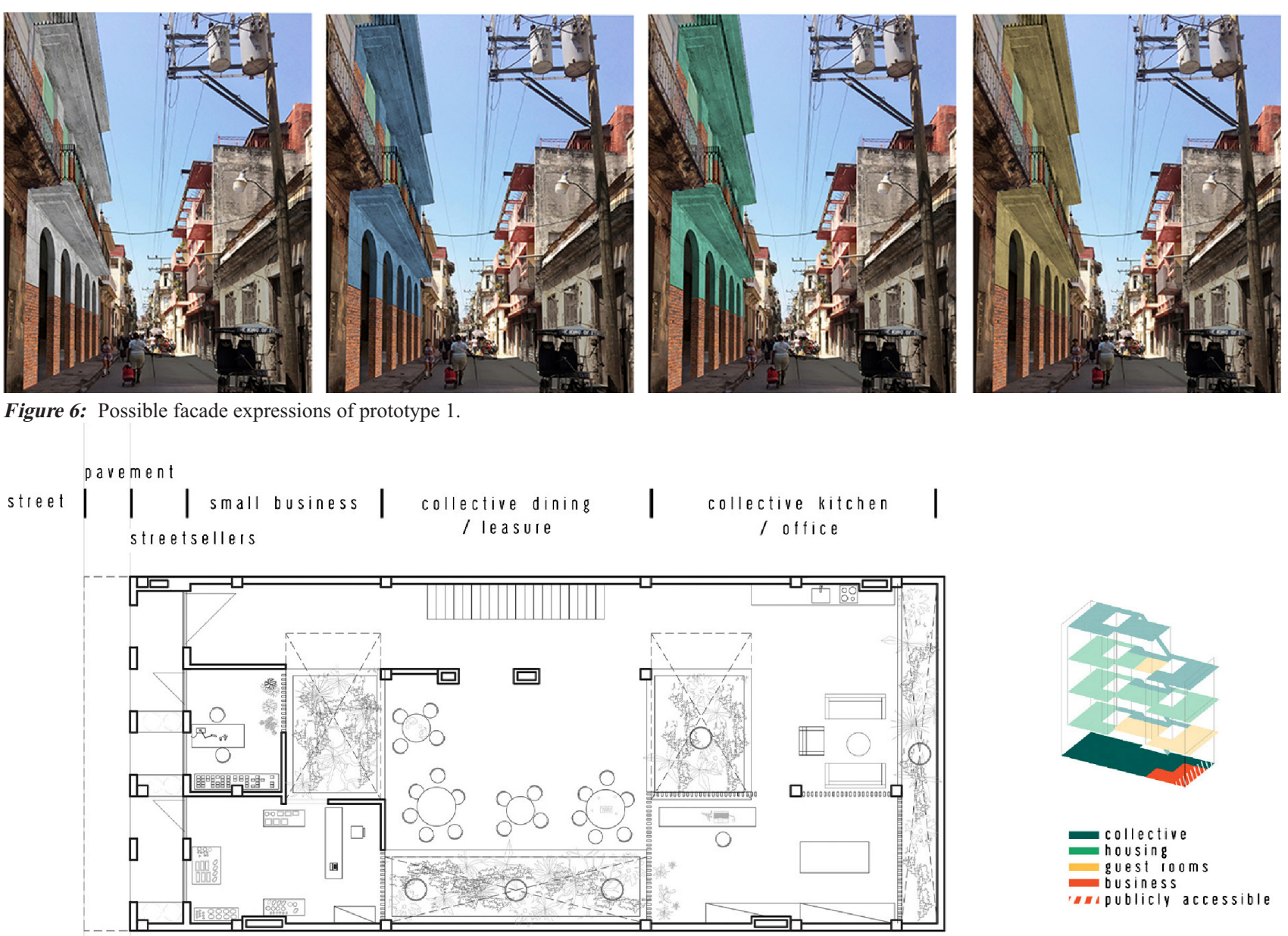

In the proposed design the front part of the ground floor addresses small Cuban emerging private businesses. Rooms for rent of ten to twenty square meters are proposed. In front of them, a space for the smallest scale of business is created, addressing street sellers. Simple benches, protected from sun and rain by the canopy of the first floor, are provided so that street sellers could prosper in comfort and do not block the already narrow sidewalks of the Old Town. The same benches can become Cuban social spots, where people can gather on the sidewalks to play domino in the evening. Offsetting of the front facade on the ground floor from the street in order to provide space for these activities can enrich the territorial sequence, adding a zone where street and domestic activities mix (Figures 6 and 7).

A second collective zone proposed would be on the roof. In its front part a roof terrace with a view on the panorama of the old town would be created. The rest of the roof would be designed for the Cuban residents as it would include a common laundry station and an urban farming element. 


\section{Process of Emerging: Cooperative Design Process}

On basis of the list of people awaiting a housing unit, the municipality is to initially define an area that requires intervention the most. After that suitable locations for a new housing building can be cataloged by the $\mathrm{OHC}$.

Later on, on each location a project that defines the structure, placement of patios, shafts and circulation can be prepared by an architect. This project will act as a base for defining the number of people that can be accommodated on given plot, and the amount of loan needed for the construction.

Next a call for participants in a housing cooperative in the area can be introduced by the municipality. On a base of received applications a suitable amount of people from a local area can be grouped into housing cooperatives, with the help of social workers.

Afterwards, based on the estimatory project, a detailed design of apartments can be created in cooperation with each future tenant, where architect is not a decision maker but an advisor. This step can be introduced in order to engage future tenants in the design process, as tenants will identify with the project strongly. Moreover, in this way more personalized apartment plans can be created.

At the same time the cooperation between the architect and future tenants is to be educational for both parties, where tenants can follow professional advice and an architect gets to understand tenant needs in more depth.

All crucial and fully permanent elements of the building would be designed by an architect, and his or her decision will shape the frame, in which a set of personalized infills would be placed. An architect will be fully responsible for the design of the main structure, circulation, placement of patios, technical shafts and the design of the front facade. As every tenant will finally be responsible for his/her own apartment design and construction, the formal outcome of the inner facades will be emergent. This possibility of expression will help tenants to identify with the project and hopefully create unexpected adjacencies of shapes, material and colors, abundant in and typical for Cuban streetscape.

As a result, a duality of facade expressions between the front and inner facades of the building will appear, and hopefully distinguish the representative front from the more introvert, domestic collective courtyards.
When construction begins, solid parts of the building designed by an architect (main structure, technical shafts, circulation and the front facade) will be constructed by a commissioned construction company, in order to grant and control its satisfactory efficiency, quality and pace.

Afterwards each tenant can be assigned with a proportional part of the budget and become responsible for the construction of personalized infills, consisting of his or her apartments, interiors and the corresponding number of hotel units. This model not only focuses on how to generate money in order to be able to build in Cuba, but also on how to spend it. The shift of responsibility for the execution of the apartments from the architect and the main construction company to the tenants will activate smaller, private service providers from bricklayers, electricians and plumbers to interior designers, that tenants will need to hire. This will allow money to trickle down to wider group of professionals, empowering the emerging Cuban private sector.

Finally when the construction process is finished, tenants can move in, and guest rooms can be registered, and this process can start to generate the money necessary to provide for the tenants and paying off the loan.

\section{THE PROPOSAL}

\section{Case Study Area}

The idea explained above was tested by proposing a couple of implementations in a south part of the Havana Vieja the area around the Jesus-Maria Street. This area is rated the lowest priority by the $\mathrm{OHC}$ and is characterized by abundance of suitable locations. This project proposed in the first place, to build on plots that are empty or occupied by a single story building and are adjacent to taller buildings. At the same time residents of this area are known for their strong attachment to the district, and are characterized as eager to create cooperative initiatives strong in collective spirit.

In order to test the idea a set of possible locations in the chosen neighborhood around Jesus-Maria Street were defined. From those, five were chosen to represent the most common situations met in Havana Vieja context: a small plot of a front width of only $4.5 \mathrm{~m}$, a medium size plot of a front width of $7 \mathrm{~m}$, a big plot of a front width of $10 \mathrm{~m}$, a corner plot and plots joined by their back borders were created. 
Plans were designed in a way that allowed easy transformation or incorporation of hotel units into housing. This gave tenants the possibility of expanding their apartments after the loan is paid off and create more housing units, further helping to ease the housing shortage.

\section{Architectural Expression and Building Technologies}

New building designs should blend in with the extraordinary fabric of Havana Vieja. Thus, each building will be designed individually in respect of the existing situation on the plot. If the plot is empty and there are no documented sources of the architecture present on that spot in the past, or it does not represent any heritage worth preserving, new designs will create quality and beauty with respect to the context of the Old Town and create architecture that seamlessly blends in within the Havana Viejas streetscape.

Buildings, in order to keep the cost and time of the realization low, will be designed using simple building technologies, that are commonly used on the island. In the designed prototypes a prefabricated concrete structure with masonry infills will be used.

\section{CONCLUSIONS}

Housing crisis among other issues is preventing Cubans from living in conditions that would allow them to prepare for and deal with challenges of today's dynamic period of Cuban history. However, if mass tourism and housing shortage is addressed in a certain way, they can complement each other financially and socially. Havana Vieja is in a great need of regeneration, both physically and socially. This change should not only reconstruct but also evolve the city towards sustainable solutions in order to create resiliency. Proposed alternative growth model for urban and social resilience to regenerate the city-center of Havana through a relation between housing and hotel shortage can, with the right help and investment, provide Havana inhabitants with necessary housing and tools to not only pay it off but also grant them a steady income source by addressing the touristic demand. This might not only make possible dealing with the housing issue sooner than currently practiced tactics, but also create an urban setup, which with the use of evenly dispersed guesthouses, decrease negative impacts of mass tourism in Havana Vieja.

\section{REFERENCES}

Achtenberg, E., 2013, Gentrification in Cuba? The Contradictions of Old Havana, NACLA, Havana.

Associated Press in Havana, 2015, "US Travel to Cuba Surges 36\% following Thaw in Diplomatic Relations", The Guardian, Havana.

Coyula, Mario, 1997, Havana Forever, Forever Havana, NACLA, Havana.

Feinberg, Richard, 2013, Soft Landing in Cuba? Emerging Entrepreneurs and Middle Classes, Brookings, Havana.

Figueras, M.A., 2003, International Tourism and the Formation of Productive Clusters in the Cuban Economy, Brookings, Havana.

Grein, J. 2015, Recent Reforms in Cuban Housing Policy, University of Chicago, Chicago.

Hunt, Nigel, 2016, “Casa Particular in Cuba: Authentic Cuban Accomodation”, Viewed 29-03-2017, from casaparticular.com

PDHL, Programa de Desarrollo Humano Loca, Cuba, 2000 'Caracterización y prioridades del Municipio de La Habana Vieja: Líneas Directrices para la III Fasedel Programa de Desarrollo Humano Local’, Cuba.

Peters, P. 2014, Cuba's New Real Estate Market, Brookings, Havana.

Rodriguez, Andrea, 2014, Cuba's Housing Crisis Worsens, Huffington Post, Havana.

Sanchez, R., 2009, Havana's Historic Architecture at Risk of Crumbling into Dust', Sun-Sentinel, Cuba. 